\title{
The effect of ruminal infusion of acetic and propionic acids on eating and rumination behaviour in sheep fed a low quality hay
}

\author{
T. Fujihara' ${ }^{1}$ M. Sakaguchi and S.A. Abdulrazak ${ }^{2}$ \\ Faculty of Life and Environmental Science. Shimane University \\ Matsue-shi, Shimane 690-8504, Japan
}

(Received 30 April 2001; revised version 26 November 2001; accepted 31 January 2002)

\section{ABSTRACT}

An experiment, to investigate the effect of changes in ruminal levels of fermentation products on cating and rumination bchaviour related to fecd utilization, acetic and propionic acids, which provided $300 \mathrm{kcal} / \mathrm{d} /$ head, is reported. Two sheep fed a hay diet alone were continuously infused VFAs into the rumen in a crossover design over 12 days period. The average daily eating time and rumination appearance (lag time after cating) tended to be prolonged with infusions of both acids, but not significantly. Daily time spent ruminating was almost similar in VFAs infused and control groups. Apparent digestibility of organic matter, crude protein and crude fibre were fairly reduced after infusion of acetic acid, although there are no changes in nutrient digestibility after propionic acid infusion. Urinary nitrogen excretion was markedly reduced, and consequently, the nitrogen retention was clearly increased after VFAs infusion, and then in particular, the retained nitrogen was significantly more after acetic acid infusion than that in control. The blood glucose level was markedly increased after propionic acid infusion, though there was no change in blood glucose level in acetic acid infusion.

From these results, it might be suggested that acetic acid or propionic acid infused at physiological level into the rumen of sheep fed on hay diet alone clearly improve the utilization of dietary nitrogen, whereas there are no clear effect on the eating and/or rumination behaviour in sheep.

KEY WORDS: rumination behaviour, shecp, acetic acid, propionic acid, feed utilization

1 Corresponding author

2 Present address: Department of Animal Science, Egerton University, P.O. Box 536, Njoro, Kenya 


\section{INTRODUCTION}

It has been shown that the time spent ruminating is obviously decreased after feeding a small particle of diet, such as crushed grains and/or ground hay, and contrary, it will be lengthened after feeding a relatively large particle of diet, such as a long hay, being due to decrease a physical stimuli to the rumen wall (Balch et al., 1951). If the animal has received same amount of diet consisted with small particle, the attack of microbes in the rumen could be much more easy as compared with that of diet consisted with large particle, because of a wide surface arca of feed particle in the former. Then, the small feed particle attacked by microbes will be further fractionalized in the rumen, and consequently their passage rate through the rumen will be more faster, i.e., an increase of passage rate and a decrease of retention time of digesta in the rumen clearly induce a reduction of time spent ruminating (Gordon, 1958). Therefore, it is obvious that the difference in species and/or characteristics of feed not only effects directly on chewing behaviour by their physical properties, but also influences indirectly the chewing behaviour with the changes in extent of ruminal fermentation (Fujihara, 1980; Fujihara et al., 1989). On the other hand, the changes in chemical composition of feed will have an influence on eating and rumination bchaviour i.e., the chewing activity will be closely related with changes in an extent of rumen fermentation (Fujihara and Nakao, 1990 a,b).

In order to investigate the effect of change in chemical composition alone in the feed on eating and rumination behaviour, it might be difficult to change the chemical composition of the diet without any changes of physical properties. In the present experiment, therefore, the eating and rumination behaviour were investigated, as well as feed utilization, under the condition changing ruminal volatile fatty acids (VFAs) concentration by continuous infusion of acetic or propionic acid into the rumen of sheep fed on hay diet alone. The VFAs infusion level was in a range that could occur after changed dietary chemical composition. Part of this work has been briefly described by Fujihara et al. (1990).

\section{MATERIAL AND METHODS}

\section{Animals and management}

Two Japanese Corriedale wethers with rumen fistula, weighing 33.8 and 34.0 $\mathrm{kg}$, were used repcatedly. They were kept in metabolism cages throughout the experimental period, and fed $2.0 \%$ dry matter (DM) per kilogram body weight per day of the sun-cured hay harvested from a predominantly Italian ryegrass pasture. The hay diet was cut to about $10 \mathrm{~cm}$ long before feeding. Chemical composition (as $\% \mathrm{DM}$ ) of the hay was as follows: organic matter, 87.1 ; crude protein, 7.3 ; crude 
fat, 2.8; crude fibre, 37.8; nitrogen-free extractives (NFE), 39.3. Fresh water and salt licks containing trace elements were available at all times. One-half of the daily ration was given at 09.00 and the other half at 17.00 .

\section{Treatments and design}

To control the effect of acids infused on energy metabolism of animals, acetic and propiomic acids were ruminally infused with buffer at a rate of $62 \mathrm{mmol}$ and 35 mmol per hour during $24 \mathrm{~h}$, respectively. These VFAs infusion levels are in a range, which will be changed in the rumen of sheep on ordinary feed, and supplied 300 $\mathrm{kcal}$ per day per head. Each acid solution was $1,000 \mathrm{ml}$ as total, and the composition of buffer was consisted of $37 \mathrm{~g}$ sodium bicarbonate $\left(\mathrm{NaHCO}_{3}\right), 19 \mathrm{~g}$ potassium bicarbonate $\left(\mathrm{KHCO}_{3}\right)$ and $4 \mathrm{~g}$ sodium chloride $(\mathrm{NaCl})$ per litre for acetic acid solution, and $40 \mathrm{~g}$ sodium bicarbonate $\left(\mathrm{NaHCO}_{3}\right)$ per litre for propionic acid solution. The composition of buffer was differed to adjust finely acid-base balance (about $\mathrm{pH} 4.5 \sim 5.0$ ) of each acid solution due to the difference in the volume of both acids infused. Each acid solution was continuously infused into the rumen with a peristaltic pump (Tokyo Rika Co., Tokyo, Japan) for $24 \mathrm{~h}$. A crossover design was adopted for treatment (acid infusion) and control in each trial (Table 1).

TABLE 1

Experimental design

\begin{tabular}{|c|c|c|c|c|}
\hline \multirow{3}{*}{$\begin{array}{l}\text { Acid infused } \\
\text { Treatment }\end{array}$} & \multicolumn{2}{|c|}{ Period I } & \multicolumn{2}{|c|}{ Period II } \\
\hline & \multicolumn{2}{|c|}{ acctic acid } & \multicolumn{2}{|c|}{ propionic acid } \\
\hline & control & infusion & control & infusion \\
\hline \multicolumn{5}{|c|}{ Allocation of animals } \\
\hline $1^{\text {si }}$ term & A & $\mathrm{B}$ & A & B \\
\hline $2^{\text {nd }}$ term* & $\mathrm{B}$ & A & $\mathrm{B}$ & A \\
\hline
\end{tabular}

- consecutive 12 days for each treatment (7-day: preliminary, 5-day: sampling)

\section{Sample collection}

In each trial, 5-day sampling period was preceded by a 7-day preliminary period, and faeces and urine were collected daily just before the morning feeding. On the final day of each period, approximately $100 \mathrm{ml}$ of ruminal contents were sampled using the stomach tube at $09.00,10.00,11.00,12.00,14.00$ and 16.00 to measure the $\mathrm{pH}$ and the concentrations of ammonia and volatile fatty acids (VFAs) in the rumen. Similarly, approximate $10 \mathrm{ml}$ of jugular blood was collected at $09.00,12.00$, 14.00 and 16.00 to determine the concentrations of glucose, urea-nitrogen and total protein in blood plasma. 
The time spent chewing during eating and ruminating were measured daily by the method of Fujihara (1980) using a wire strain gauge on the lower jaw (Harumoto and Kato, 1979) during 5-day sampling period in each period. The term used in this paper to indicate the rumination behaviour are the same as in the previous report of Fujihara (1981) based on the work of Gordon (1955).

\section{Analytical methods}

Nitrogen in the diet, faeces and urine were analyzed by the Kjeldahl method, and the contents of crude fat, crude fibre and crude ash in the diet and faeces were determined by AOAC method (1960).

Ruminal $\mathrm{pH}$ value was measured by a glass-electrode method using a $\mathrm{pH}$ meter (Horiba M.8L, Horiba Seisakusho Co., Kyoto, Japan). Ammonia in the ruminal fluid was analyzed by the method of Oser et al. (1965), and VFAs were determined by gas chromatography (Erwin, et al., 1961). Glucose, urea-nitrogen and total protein in blood plasma were analyzed using the Unitest System (Model 300, Biodynamics, Inc, USA).

Test for significance of difference between two groups was done by $t$-test.

\section{RESULTS}

\section{Apparent digestibility and nitrogen balance}

As shown in Table 2, digestibility of organic matter, crude protein, crude fibre and NFE tended to decrease after infusion of acetic acid as compared with that in control, but not significantly $(\mathrm{P}>0.05)$. On the other hand, the digestibility of organic matter and NFE tended to increase $(\mathrm{P}>0.05)$ after infusion of propionic acid than that in control, but not significantly.

In nitrogen balance, the urinary nitrogen excretion was markedly lower after infusion of acetic acid than that in control, and consequently, retained nitrogen was 2 times more in the former than in the latter $(\mathrm{P}<0.05)$. After infusion of propionic acid, the urinary nitrogen excretion was also lower than that in control, and then, as a result, the retained nitrogen tended to increase in the former than in the latter, but not significantly $(\mathrm{P}>0.05)$.

\section{Eating and rumination behaviour}

The time spent eating relatively changed daily after infusion of acetic acid, and the range of daily variation was about $80 \mathrm{~min}$, whereas it was almost constant during consecutive 5 days in control (Table 3 ). As a result, average daily time spent 
TABLE 2

Apparent digestibility of nutrients and nitrogen balance in sheep fed on hay with ruminal infusion of VFAs

\begin{tabular}{|c|c|c|c|c|c|c|}
\hline \multirow{2}{*}{ 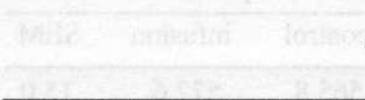 } & \multicolumn{3}{|c|}{ Acetic acid } & \multicolumn{3}{|c|}{ Propionic acid } \\
\hline & control & infusion & SEM & control & infusion & SEM \\
\hline \multicolumn{7}{|l|}{ Apparent digestibility, $\%$} \\
\hline organic matter & $54.4^{1}$ & 51.2 & 0.9 & 53.5 & 54.3 & 0.2 \\
\hline crude protein & 50.1 & 46.0 & 0.2 & 47.0 & 46.1 & 1.2 \\
\hline crude fat & 59.7 & 59.8 & 6.3 & 55.3 & 55.3 & 4.3 \\
\hline crude fibre & 64.0 & 59.5 & 0.9 & 62.3 & 62.3 & 1.4 \\
\hline $\mathrm{NFE}^{2}$ & 46.8 & 43.6 & 0.8 & 46.2 & 47.4 & 0.8 \\
\hline \multicolumn{7}{|l|}{ Nitrogen balance, $\mathrm{g} / \mathrm{Kg}^{0.75} / \mathrm{d}$} \\
\hline total intake & 0.53 & 0.53 & 0.00 & 0.55 & 0.55 & 0.00 \\
\hline faecal & 0.26 & 0.28 & 0.00 & 0.29 & 0.29 & 0.01 \\
\hline urinary & $0.20^{\mathrm{a}}$ & $0.12^{\mathrm{b}}$ & 0.01 & 0.22 & 0.18 & 0.03 \\
\hline retention & $0.06^{\mathrm{a}}$ & $0.12^{\mathrm{b}}$ & 0.02 & 0.04 & 0.07 & 0.04 \\
\hline retained $\mathrm{N} /$ digested $\mathrm{N}, \%$ & $24.4^{\mathrm{a}}$ & $50.1^{\mathrm{b}}$ & 4.3 & 15.5 & 28.9 & 13.2 \\
\hline
\end{tabular}

TABLE 3

Eating behaviour in sheep fed on hay with ruminal infusion of VFAs

\begin{tabular}{|c|c|c|c|c|c|c|}
\hline & \multicolumn{3}{|c|}{ Acetic acid } & \multicolumn{3}{|c|}{ Propionic acid } \\
\hline & control & infusion & SEM & control & infusion & SEM \\
\hline Time spent eating, $\min$ & $244.3^{1}$ & 244.9 & 4.1 & 232.7 & 248.3 & 18.0 \\
\hline Rate of eating, g DM/min & 2.63 & 2.64 & 0.13 & 2.85 & 2.67 & 0.14 \\
\hline Rumination appearance ${ }^{2}$ & 114.5 & 140.2 & 8.0 & 104.8 & 124.2 & 17.0 \\
\hline
\end{tabular}

1 mean of 10 observations ( 2 animals $\times 5$ days)

${ }^{2}$ time after eating (lag time) $(\mathrm{min} / \mathrm{d})$

eating was almost the same in both groups. After infusion of propionic acid, daily time spent eating and eating rate tended to increase as compared with that in control, but not significantly $(\mathrm{P}>0.05)$. Rumination appearance (lag time after eating) clearly tended to be longer after infusion of acids as compared with that in control, and the difference of values between treatment and control was greater after infusion of acetic acid than after infusion of propionic acid.

In rumination behaviour (Table 4), daily time spent ruminating and daily number of boli tended to be smaller $(\mathrm{P}>0.05)$ in acetic infused than control group. As a 
TABLE 4

Rumination behaviour in sheep fed on hay with ruminal infusion of VFAs

\begin{tabular}{|c|c|c|c|c|c|c|}
\hline & \multicolumn{3}{|c|}{ Acctic acid } & \multicolumn{3}{|c|}{ Propionic acid } \\
\hline & control & infusion & SEM & control & infusion & SEM \\
\hline Time spent ruminating, min & $580.6^{1}$ & 575.4 & 10.0 & 565.8 & 572.6 & 15.0 \\
\hline $\begin{array}{l}\text { Daily number of boli } \\
\text { regurgitated }\end{array}$ & 580.2 & 569.6 & 34.0 & 550.3 & 585.5 & 6.0 \\
\hline $\begin{array}{l}\text { Daily number of rumination } \\
\text { periods }\end{array}$ & 19.6 & 23.9 & 2.5 & 25.0 & 23.9 & 2.5 \\
\hline Cyclic rate ${ }^{2}$ & 60.2 & 60.9 & 2.6 & 61.8 & 58.7 & 1.7 \\
\hline
\end{tabular}

1 mean of 10 observations ( 2 animals $x 5$ days)

${ }^{2}$ total rumination time ( $\mathrm{sec}$ )/no. of boli regurgitated (see Gordon, 1961)

result, the rumination index (time spent ruminating per $100 \mathrm{~g} \mathrm{DM}$ ) (Table 5) was slightly lesser $(\mathrm{P}>0.05)$ with acetic acid infused than control group.

TABLE 5

Rumination efficiency in sheep fed on hay with ruminal infusion of VFAs

\begin{tabular}{lcccccccc}
\hline & \multicolumn{3}{c}{ Acetic acid } & & \multicolumn{3}{c}{ Propionic acid } \\
\cline { 8 - 9 } & control & infusion & SEM & & control & infusion & SEM \\
\hline Rumination index & $90.4^{2}$ & 90.1 & 5.5 & & 85.6 & 86.6 & 5.5 \\
No. of chews/bolus & 72.3 & 75.0 & 8.0 & & 66.8 & 62.3 & 5.0 \\
Bolus time, sec. & 51.1 & 54.2 & 4.3 & & 53.4 & 49.8 & 2.3 \\
Chewing rate & 83.6 & 83.0 & 2.8 & & 74.8 & 75.1 & 2.5 \\
\hline
\end{tabular}

1 time spent ruminating/100 g DM eaten (see Fujihara, 1980)

2 mean of 10 observations ( 2 animals $x 5$ days)

$p H$ value and the concentrations of ammonia and VFAs in rumen fluid

The $\mathrm{pH}$ value in rumen fluid was fairly lower after infusion of acetic acids than that in control, and the concentration of ammonia in rumen fluid was also lower after infusion of acetic acid than in control (Table 6). Contrarily, the concentration of VFAs in the rumen fluid was about 1.5 times higher after infusion of acetic acid than that in control would be due to infusion of acid.

After the infusion of propionic acid, ruminal $\mathrm{pH}$ value tended to be higher than in control, and this is an opposite result after acetic acid infusion described above. The ruminal level of ammonia tended to be lower after infusion of propionic acid than after control, and contrarily, the level of VFAs in rumen fluid was fairly higher $(\mathrm{P}>0.05)$ in the former than in the latter, but the extent of difference between the 
TABLE 6

The $\mathrm{pH}$ value and the concentrastions of ammonia and VFAs in the rumen fluid of sheep fed on hay with ruminal infusion of VFAs

\begin{tabular}{|c|c|c|c|c|c|c|}
\hline & \multicolumn{3}{|c|}{ Acetic acid } & \multicolumn{3}{|c|}{ Propionic acid } \\
\hline & control & infusion & SEM & control & infusion & SEM \\
\hline $\mathrm{pH}$ value & $6.90^{1}$ & 6.78 & 0.04 & 6.84 & 6.92 & 0.08 \\
\hline Ammonia, mg/dl & 9.70 & 9.07 & 0.14 & 9.52 & 7.76 & 0.20 \\
\hline VFAs, $\mathrm{mmol} / \mathrm{dl}$ & 6.82 & 10.21 & 0.78 & 6.75 & 7.89 & 0.74 \\
\hline \multicolumn{7}{|c|}{ Composition of VFAs, mmol/dl } \\
\hline acetic acid & 5.35 & 9.07 & 0.67 & 5.19 & 4.14 & 0.39 \\
\hline propionic acid & 1.01 & 0.83 & 0.06 & 1.15 & 3.40 & 0.34 \\
\hline butyric acid & 0.41 & 0.28 & 0.02 & 0.37 & 0.32 & 0.03 \\
\hline
\end{tabular}

' mean of 12 samples ( 2 aninals $\times 6$ times)

acid infusion and the control was smaller than that observed after the infusion of acetic acid.

Infusion of acetic acid resulted to an increase in acetic acid but reduced the concentrations of propionic, butyric and iso-valeric acids in the rumen fluid. This clearly showed an extent of ruminal fermentation would be depressed by acetic acid infusion.

In the treatment of propionic acid, the ruminal concentration of propionic acid was about two times heightened after the infusion of propionic acid, and there were no phenomenon to decrease the levels of the other volatile fatty acids as shown in the treatment with acetic acid.

The changes in glucose, urea and total protein in the plasma

The concentrations of glucose and total protein in blood plasma (Table 7) were not changed after the infusion of acetic acid into the rumen. The slight decrease of

TABLE 7

The concentrations of glucose, urea nitrogen and total protein in blood plasma of sheep fed on hay with ruminal infusion of VFAs

\begin{tabular}{lcccccccc}
\hline & \multicolumn{3}{c}{ Acetic acid } & & \multicolumn{3}{c}{ Propionic acid } \\
\cline { 2 - 3 } \cline { 7 - 9 } & control & infusion & SEM & & control & infusion & SEM \\
\hline Glucose, $\mathrm{mg} / \mathrm{dl}$ & $42.3^{\prime}$ & 42.1 & 2.2 & & $44.4^{*}$ & $49.4^{\mathrm{b}}$ & 0.9 \\
Urea-nitrogen, $\mathrm{mg} / \mathrm{dl}$ & 11.0 & 8.9 & 1.0 & & 9.5 & 8.7 & 0.7 \\
Total protein, $\mathrm{g} / \mathrm{d} \mathrm{l}$ & 6.0 & 6.1 & & 0.3 & & 6.3 & 5.9 & 0.2 \\
\hline
\end{tabular}

1 mean of 8 samples ( 2 animals $x 4$ times)

a,b values with different superscript letters differ at $\mathrm{P}<0.05$ 
plasma level of urea would be due to decrease of ammonia in the rumen after the infusion of acetic acid.

Contrary, the plasma glucose level was fairly elevated $(\mathrm{P}<0.05)$ by ruminal infusion of propionic acid, and this could be due to a reflection of propionic acid as a precursor of glucose. The level of plasma total protein did not change after the treatment of propionic acid. The slight decrease of plasma urea level after infusion of propionic acid, would be as a result of the level of ammonia in the rumen.

\section{DISCUSSION}

On the digestibility of dietary nutrients, the digestibility of $\mathrm{OM}$, crude protein, crude fibre and NFE tended to decrease after the ruminal infusion of acetic acid, and contrarily, there was no clear pattern on nutrient digestibility after the infusion of propionic acid. In general, the main reason for decrease of nutrient digestibility in ruminants has been thought to be an increase of passage rate of ruminal digesta and/or a clear decrease in activity of rumen microbes. In the present experiment, there was no change in the time spent ruminating and the number of boli regurgitated, which has been thought to be closely related with the passage rate of digesta from the rumen, after the infusion of acetic acid. On the other hand, the cyclic rate, which has been thought to be closely related to a lowered movement of reticulorumen, tended to be relatively longer after the infusion of acetic acid. Therefore, the decrease in digestibility of nutrients after infusion of acetic acid would be due to a decrease in microbial activity in the rumen, because it will be closely related to movement of the reticulo-rumen as mentioned above. The ruminal ammonia concentration, which will be an indicator showing an extent of rumen fermentation, however, tended to decrease after infusion of acetic acid than in control. Similarly, the levels of other VFAs (propionic, butyric and iso-valeric acids) except acetic acid were also reduced after infusion of acetic acid as compared with that in control. In this experiment, the acetic acid was infused with buffer solution to avoid an acute effect on ruminal condition. The ruminal $\mathrm{pH}$ value generally decrease in proportion to the level of VFAs (Weston and Hogan, 1968), then the acid infusate was slightly acidified to reappear the general aspect in the present experiment (acetic acid solution: 4.5 , propionic acid solution: 5.0 ). It is generally accepted that the decrease of ruminal $\mathrm{pH}$ will suppress the microbial activity, in particular cellulolytic bacteria, in the rumen. Therefore, the decrease of $\mathrm{pH}$ value after infusion of acetic acid in this experiment probably prevented the degradation of fibre fraction in the ration.

Likewise, the decrease in ruminal $\mathrm{pH}$ value after infusion of acetic acid is also thought to be related with the prolonged rumination appearance after the infusion of acetic acid in this study, because it has been reported that the lag time after eating 
clearly increase and the appearance of rumination activity also is reduced when the ruminal $\mathrm{pH}$ valuc is relatively low (Pearce and Moir, 1964; Pearce, 1965). About the reason why rumination activity does not occur immediately after eating, it is also thought to decrease a physical stimulation of ingesta swallowed to the rumen wall due to coating by mucoprotein in the saliva. In the case of acetic acid-infusion, the activity of cellulolytic bacteria weakened under the low ruminal $\mathrm{pH}$ and delayed further the degradation of mucoprotein in the rumen as compared with that in control. After the infusion of acetic acid, the daily time spent ruminating and number of boli regurgitated, as well as rumination appearance, which is thought to relate to movement of the reticulo-rumen was relatively lower than that in control. This indicated that the motility of the reticulo-rumen was relatively weakened after the infusion of acetic acid as compared with that in control. The infusion of acetic acid clearly (1.5 times) increased the VFAs, in particular acetic acid concentration in the rumen, resulting to increase the amount of acetic acid in the digesta leaving the rumen and flowing into the lower gut in the circumstance. There will be, therefore, some reduction of rumination activity caused by an increase of acid concentrations in the digesta leaving abomasum, because it has been reported that an increase of acetic acid level in the duodenal digesta obviously reduce a motility of the reticulorumen (Yamasaki, 1986).

On the other hand, daily time spent ruminating and the daily number of boli regurgitated after the infusion of propionic acid were almost the same as that in control, and there was no effect of ruminal acid infusion on a motility of the reticulo-rumen. The fact that the ruminal infusion of propionic acid did not have any effect on a motility of reticulo-rumen and on the rate of passage of digesta through the rumen seems to be closely related to lack of difference in apparent digestibility of nutrient between propionic acid infused and control group. This would be due to relatively low level of propionic acid infused in this experiment, and therefore, it is clear that the propionic acid infused at low level would has no remarkable effect on the reticulo-ruminal contractions.

The calorie per gram of acetic acid and propionic acid is 3.35 and $4.87 \mathrm{kcal}$, respectively, and the total energy of each infusate of both acids was similar ( 300 $\mathrm{kcal} /$ day). Therefore, the molarity of propionic acid solution was lower than that of acetic acid solution. In the experiment with duodenal infusion of VFAs in ruminant, it has been reported that the feed intake and reticulo-ruminal motility were markedly influenced with acetic acid-infusion at physiological level, although that was influenced witl propionic acid-infusion at 20 times of physiological level(Yamasaki, 1986). Likcwisc, in the present experiment, the fact that the effect of ruminal infusion of propionic acid on daily rumination time and/or number of boli regurgitated, which is thought to relate with the reticulo-ruminal motility, was lesser than that after the infusion of acetic acid would be due to a relatively low level of ruminal VFAs in the former than in the latter. 
Gencrally, in ruminant animals propionic acid appears little in the peripheral blood, whereas acetic acid appears in some extent $(0.3-1.0 \mathrm{mmol} / \mathrm{dl})$ in the blood. In the present experiment, however, the effects of levels of some organic acids, such as acetic and propionic acids in the peripheral blood on the feed intake and/or rumination behaviour was not clear.

No negative balance observed after infusions of acetic and propionic acids as well as control, and this obviously indicates that the hay used as a basal diet contained the enough amount of nitrogen to meet the requirement of animals. On the retained nitrogen, the figures in infused group were quite high as compared with control group. In the partitioning of absorbed protein in the body, it is generally recognized that an energy supply take precedence over protein synthesis in the animal body, and therefore, if energy intake is relatively low, the amounts of protein and/or amino acids to be used for energy supply will be increased, consequently, protein synthesis will be decreased in the body. In other word, the amount of nitrogen for protein synthesis obviously increase when some carbohydrates and/or lipids was supplemented as an energy source. In the present study, the organic acids (acetic and propionic acids) infused ruminally is clearly thought to contribute as an energy source for protein sparing in animal body, i.e., an increased retained nitrogen after infusion of acetic and propionic acids could be due to increase of energy supply from acetic acid or propionic acid as compared with that in control. It also seems that propionic acid will be relatively superior to acetic acid as a glucogenic substance in ruminant animals (Armstrong and Blaxter, 1957; Eskeland et al., 1974).

In conclusion, the results suggest that acetic acid or propionic acid supplied additionally at physiological level into the rumen of sheep fed on hay diet alone clearly improves the utilization of dietary nitrogen, with no clear effect on the eating and/or rumination behaviour in sheep.

\section{REFERENCES}

AOAC, 1960. Association of Official Analytical Chemists, Official Method of Analysis. $9^{\text {th }}$ Edition. Washington, DC, pp. 283- 288

Armstrong D.G., Blaxter K.L., 1957. The heat increment of steam-volatile fatty acids in fasting sheep. Brit. J. Nutr. 11, 247-272

Balch C.C., Kelly A., Heim G., 1951. Factors affecting the utilization of food by dairy cows. 4 . The action of the reticulo-omasal orifice. Brit. J. Nutr. 5, 207-216

Erwin E.S., Marco G.J., Emery E.M., 1961. Volatile fatty analyses of blood and rumen fluid by gas chromatography. J. Dairy Sci. 44, 1768-1774

Eskeland B., Pfander W.H., Preston R.L., 1974. Intravenous energy infusion in lambs: effects on nitrogen retention, plasma free amino acids and plasma urea nitrogen. Brit. J. Nutr. 31, 202-212

Fujihara T., 1980. The eating and rumination behaviour in sheep fed only grass diets in either the fresh or dried form. J. Agr. Sci. 95, 729-732 
Fujihara T., 1981. Eating and rumination behaviour in sheep given silage nade from the fibrous residue of ladino clover. J. Agr. Sci. 97, 485-488

Fujihara T., Maeda S., Harumoto T., 1990. The effect of ruminal infusion of VFAs on the eating and rumination behaviour in sheep fed only hay. Proceedings of $5^{\text {th }}$ AAAP Animal Science Congress, Vol. 3, p. 87 Taipei (Taiwan)

Fujihara T., Nakao T., 1990a. The eating and rumination behaviour in sheep fed the silages made from the fibrous residues of broad bean (Vicia faba L.) and lucerne (Medicago sativa L.) with timothy (Phleum pratense L.) hay. Jpn. J. Zootech. Sci. 61, 666-669

Fujihara T., Nakao T., 1990b. The eating and rumination behaviour in sheep fed the diet of silage made from fibrous residuc ieft after the extraction of ladino clover (Trifolium repens L. var. giganteum) leaf protein with timothy (Phleum pratense L.) hay. Jpn. J. Zootcch. Sci. 61, 757-761

Fujihara T., Sumida M., Harumoto T., 1989. The effect of water consumption on the eating and rumination behaviour of sheep fed only fresh or dried forage. Jpn. J. Zootech. Sci. 60, 387-395

Gordon J.G., 1955. Rumination in the sheep. Ph.D. Thesis, University of Aberdeen (UK)

Gordon J.G., 1958. The relationship between fineness of grinding of food and rumination. J. Agr. Sci. $51,78-80$

Harumoto T., Kato M., 1979. Effect of different amounts of hay intake on the rumination behaviour in sheep (in Japanese). Jpn. J. Zootech. Sci. 50, 155-160

Oser B.L. (Editor), 1965. Hawk's Physiological Chemistry. 14 $4^{\text {th }}$ Edition. McGraw Hill Co., New York, pp. 1219-1220

Pearce G.R., 1965. Rumination in sheep. II. The circadian pattern of rumination. Aust. J. Agr. Res. 16, 635-648

Pearce G.R., Moir R.M., 1964. Rumination in sheep. I. The influence of rumination and grinding upon the passage and digestion of food. Aust. J. Agr. Sci. 15, 635-644

Weston R.H., Hogan J.P., 1968. The digestion of pasture plants by sheep. 1. Ruminal production of volatile fatty acids by sheep offered diets of ryegrass and forage oats. Aust. J. Agr. Res, 19, 419432

Yamasaki K., 1986. The function of lower gut in sheep; in particular with the gastric motility (in Japanese). Proceedings of Japanese Socicty of Animal Nutrition and Metabolism 30, 27-40

\section{STRESZCZENIE}

Wplyw infuzji kwasów octowego i propionowego do żwacza na tempo pobierania paszy i przeżuwanie u owiec żywionych sianem niskiej jakości

Celem doświadczenia było zbadanie wpływu podawania do źwacza kwasów octowego i propionowego $\mathrm{w}$ ilości odpowiadającej $300 \mathrm{kcal} / \mathrm{dzicn} / \mathrm{sztuka}$, na tempo pobierania paszy, przeżuwanie i wykorzystanie paszy przez owce. Dwóm owcom, żywionym tylko sianem, infundowano do żwacza przemiennie w/w kwasy przez 12 dni. Stwierdzono tendencję do przedłużania się średnicgo czasu pobierania paszy oraz rozpoczęcia i czasu przeżuwania po jedzeniu przy infuzji obydwóch kwasów, lecz nic potwierdzoną statystycznie. Czas spędzony na przeżuwaniu w ciągu dnia był niemal jednakowy u owiec otrzymujących kwasy i kontrolnych. Pozorna strawność substancji organicznej, białka ogólnego i włókna była obniżona po infuzji kwasu octowego, nie stwierdzono natomiast różnic między zwierzętami kontrolnymi i otrzymującyıni kwas propionowy. llość azotu wy- 
dalanego z moczem była istotnie mniejsza $(\mathrm{P}<0,05)$ przy infuzji kwasu octowego, czego następstwem było zwiększenie $(\mathrm{P}<0,05)$ retencji azotu. Stężenie glukozy we krwi było podobne u owiec otrzymujących kwas octowy i u kontrolnych, natomiast większe $(\mathrm{P}<0,05) \mathrm{u}$ owiec, którym infundowano kwas propionowy.

Na podstawie otrzymanych wyników można sądzić, że podawanie do żwacza, w ilościach fizjologicznych, kwasów octowego i propionowego owcom żywionym tylko sianem poprawia wykorzystanie azotu, natomiast nie ma wyraźnego wpływu na pobieranie paszy i przeżuwanie. 